\title{
Factor Influencing Depersonalization on Prison Employees
}

\author{
Msc. Marinela Pane \\ Department of policy and social work, Faculty of social science, University of Albania
}

\begin{abstract}
The prison staff is a key factor in the progress of the institution which means that their behaviour directly affects the services it provides. Prisons aim serving the sentence and rehabilitation of prisoners. If the employees of the institution will feel tired, stressed, consume professionally then decrease their effectiveness and performance, which has a direct effect on the life of a prisoner. Professionals dehumanized do not help in achieving the final goal of rehabilitation and teaching positive behaviour of prisoners. This study investigates one of three dimensions of burnout, depersonalization. The aim is to measure the level of depersonalization of the prison staff and to identify the factors influencing it. Quantitative research method was used for data collection and analyse. Cristina Maslach Inventory is completed from 290 participants, aiming to measure the level of depersonalization. The study found out that male professionals, divorced, those who work with the target of the men, and an employee who had a great distance from the place of work were more dehumanized. The quality of relationship with superiors and colleagues affects depersonalization. The less level of communication and cooperation in organization the higher is the level of emotional exhaustion, consequently the level of depersonalization is higher. As conclusion the prevalence of depersonalization is evident in prison staff, but in low levels. Dominant factors influencing depersonalization are the quality of relationship with superiors and colleagues.
\end{abstract}

Keywords: Depersonalization, prison staff, stress.

\section{Introduction}

Work with individuals is one of the most difficult professions, because human beings are complex and complicated. Staff members in human services and educational institutions spend considerable time in intensive involvement with other people. Interaction client / staff is focused on client physical, social and psychological problems, therefore is loaded with feelings of fear, anger, despair, embarrassment, because solutions to client problems are not always clear and simple but become more ambiguous and frustrating. Burnout is psychological and biological term that is defined as a physical, emotional and mental fatigue caused by exposure for a long time the individual to situations or emotional stressors that cause fatigue. Burnout prevents professionals to be more effective in their work. Among the most vulnerable professions consumption are professional teachers, social workers and police officers. Employees of prisons and detention are at risk of burnout due to work with difficult "clients", risks. Given the desire and commitment, the professionals often forget their personal needs. Although they may have many professional skills, often they are unaware of the existence of the so-called "Burnout" and the impact that it has on the efficiency and quality of their work. According to Maslach ,(Maslach 1996) burnout is :"A syndrome of emotional exhaustion, depersonalization and personal accomplishment very few, can occur between individuals that work. "

Burnout (Maslach 1996) is a heavy psychological condition caused by chronic stress at work and that brings:

1. Drain the energy and emotional exhaustion

2. Low resistance to disease

3. Growing discontent and pessimism 


\section{Increased absenteeism and efficiency at work}

\section{Increasing of depersonalization in interpersonal relations}

Correctional officers are part of a unique work environment. Working in a prison is a stressful, demanding, and socially important job. Research has found that the perceived dangerousness of the work, as a result of threats and inmate violence is a significant cause of stress for many correctional staff. One possible outcome of prolonged or chronic stressors at the work place is burnout .In correctional staff, work stress and burnout can lead to negative outcomes such as decreased physical health, internal withdrawal, and inability to cope with traumatic experiences, increased substance use.

Employees of prisons and detention are those who want to help prisoners and serve them in solving problems including the complexity of the situation in which they are. These employees need to believe in the possibility for growth and development of human beings and their capacity to change throughout life. Occupation of prison system employees $I$ detention is a profession that can't be excluded from conflict, so they should be prepared that will withstand various stresses and strains of their work. If these employees will know before these problems, will be more prepared to solve and will be easier to accept them. Every job or profession brings with it stress or conflicts. Professional skills emerge in how professionals accept the problem and if they find the most suitable ways to cope it.

Employees of prisons / detention, work with individuals of different age, different origins, who have different problems and have damaged, individuals and communities through the criminal action they have done. The employees have a large number of inmates to serve at a certain time, so he / she may feel overloaded. So, what should consider is the fact that he may never act over its capacity. In these cases it should use professional skills to decide which are jobs or tasks that must be performed before and what can wait a period of time. In burnout of prison / detention employees, can affect a number of factors, most important of which are:

- Prison staff often work with individuals who have problems that affect the lives of employees also. These problems are often intense, personal and volatile.

- Many employees have heavy workloads and a compulsory routine to follow every day.

- Risks facing prison staff / detentions are different. Trying to escape, violence, strife, hostage-taking, are dangerous situations with which these employees may face in their work.

-Working in prisons / detention is huge pressure to get maximum efficiency and no problem.

This often causes burnout. In this study is explored one of the three subscales of burnout, depersonalization. Depersonalization refers to a negative reaction, feeling, and a kind of detachment from other people, which can often include loss of idealization. Usually it develops as a reaction to emotional exhaustion and considered as a means to protect them. But the danger is that this disconnect can be converted into dehumanize, losing touch with themselves, it is possible that they do not see themselves or others as valuable. The person also loses track of their personal needs. Their view of life restricts to see at the present time, and their life becomes a series of mechanical functions

Variables such as age, gender, education level, experience, distance from work, participation in training, relationship with colleagues and superiors are independent variables and are easier to define. These influence, encourage, cause the situation, depersonalization that is dependent variable. The dependent variable is the one that influenced and preceded by independent variable .Dependent variable is depersonalization, the issue of interest of researcher. One of the ways to understand social science research is the notion that if something can be determined, then can be measured.

\section{The goal}

The goal is to estimate the level of depersonalization of the prison staff and to identify the factors influencing it. 


\section{Objectives}

- To estimate the level of depersonalization of the prison staff

- To understand which are the factors influencing depersonalization on prison staff

- To identify personal and organizational strategies and techniques to be used for the prevention and treatment of this phenomenon.

\section{Research questions}

- How is the prevalence of depersonalization on prison staff?

- Which are the factors influencing depersonalization on prison staff?

- What are the measures that should be taken to prevent and reduce the depersonalization level?

\section{Methodology}

Methods used to fulfill the aim and objectives of the need assessment were based on primary and secondary data collection and analyze. The methodology that is used is quantitative method of data collection. The model is exploratory. This was achieved through scientific methods and instruments. This study is based on a concrete reality and in certain categories of individuals, so in Albanian reality and with employees of the penitentiary system. A crucial part of the study was literature and desk review process. Through which were search, assessed and synthesis all relevant studies and other source materials related with areas in the study focus. Also identification and analysis of the existing data gathered from the system on the number category and number institutions were key part of data collection and analysis. The study will followed a quantitative methodology through consisting of questionnaire.

\section{Participants in the study and sample}

The participants in the study were all prisons employee of Republic of Albania, consists of 4100 persons. Population refers to all employees of the penitentiary system including the security and civil staff. The structure is divided into two parts. In the military structure which is tasked only preserving, securing prisons and escorting prisoners and civil structure that is in charge of training and rehabilitation. According to data of DPB, institutions of criminal judgments execution throughout the Republic Of Albania are : prisons of Elbasan, the Kavaja Institution, Ali Demi, Jordan Misja (313), Mine Peza (302), Vaqarr, Durres, Peqin, Kukës , Tropoje, Berat, Kruje, Fushe Kruje, Lezha, Vlore, Tepelena, Rrogozhine, Fier, Lushnje, Saranda, Korca and the prison hospital. This is the list of institutions where work target group, interested researchers.

\section{Sample}

In this paper, the probability sampling is used through the sampling technique by stages. Sample by stages including sample selection by a stage sequentially, each sample is selected by previously selected sample. The sample consisted of employees, who were selected to participate in the study, here preserved the principle of randomization .In a study population of 23 institutions, researcher randomly chose 13 of them .In a box 23 pieces of paper have been introduced which were written the prisons names. Randomly are selected 13 of them. It is deemed appropriate and number substantial to represent the population. Institutions of penitentiary system where the study was conducted, are prisons of Elbasan, Kavaja Institution, Ali Demi, Mine Peza (302), Vaqarr, Durres, Peqin, Krujë, Vlora, Rrogozhinë, Fier, Korca, and prison hospital. In each institution are randomly selected employees who offer us a total of 290 persons sample to be included in the study. Were distributed an equal number of questionnaires, after all penitentiary institutions have approximately a number of employees. They were targeted 351 questionnaires with margin of error of $5 \%$ and $95 \%$ confidence interval. From them only 290 were completed, then the rate of return of responses is 290 questionnaires translated into $82.6 \%$. 
Table 1. Distribution of government employees involved in the study by districts.

\begin{tabular}{|c|c|c|c|}
\hline Institutions involved in sample & $\begin{array}{l}\text { Number of } \\
\text { questionnaires } \\
\text { distributed (target } \\
\text { sample) }\end{array}$ & $\begin{array}{l}\text { Number of completed } \\
\text { questionnaires (sample conducted) }\end{array}$ & $\begin{array}{l}\text { The level of return } \\
\text { responses }\end{array}$ \\
\hline PRISON Korcë & 27 & 25 & $92.5 \%$ \\
\hline PRISON Fier & 27 & 22 & $81.5 \%$ \\
\hline PRISON Rrogozhinë & 27 & 20 & $74 \%$ \\
\hline PRISON Vlorë & 27 & 22 & $81.5 \%$ \\
\hline PRISON Krujë & 27 & 22 & $81.5 \%$ \\
\hline Prison hospital & 27 & 22 & $81.5 \% \%$ \\
\hline PRISON Elbasan & 27 & 20 & $74 \%$ \\
\hline PRISONMinePeza(302), & 27 & 22 & $81.5 \%$ \\
\hline PRISON Ali Demi & 27 & 25 & $92.5 \%$ \\
\hline PRISON Peqin & 27 & 22 & $81.5 \%$ \\
\hline PRISON Vaqarr & 27 & 22 & $81.5 \%$ \\
\hline PRISON Kavajë & 27 & 25 & $92.5 \%$ \\
\hline PRISON Durrës & 27 & 21 & $77.8 \%$ \\
\hline TOTAL & 351 & 290 & $82.6 \%$ \\
\hline
\end{tabular}

\section{Instrument for data collection}

351 questionnaires were targeted. The questionnaire was anonymous, where the information is provided in good faith and identity of the respondents is not know. The way of questionnaire completing was to self-rule. This instrument is selected to measure attitudes through component, behavioral, affective and cognitive. (Pettijon.'F.T 1996)The questionnaire was constructed from two sections.

- In the first section, the questionnaire seeks demographic information from entities that have to do with gender, education, age, position, distance from work, marital status ect. .This section contains 14 questions.

- In the second section are questions requiring information about the attitudes of employees. This section contains 22 questions. These questions are fixed and immutable. The intervention is made only to the demographic data that are adjusted to reality, to see the dynamics and linking several variables. This section contains questions that assess three levels of Burnout such as emotional exhaustion, depersonalization, and personal accomplishment.

\section{Maslach Burnout Inventory}

This inventory has three subscales and is very simple to be administrated. This inventor is designed around three syndromes aspects of burnout, emotional exhaustion, depersonalization and personal accomplishment. However, is the most widely scientific methods used for measuring burnout .It is powered by Maslach et al.(2001) and (Maslach \& Jackson 1981), known as the Maslach Burnout Inventory 
This is the only instrument that assesses three dimensions of burnout and is known like scale that has the strongest psychometric characteristics. This instrument includes three subscales and evaluates various aspects of the practical burnout. It resulted to be reliable, valid and easy to administer (Maslach et al. 2001)

\section{Results}

\section{Background information of respondents}

Based at the demographic data, the majority of respondents are men around (68\%). This is because the vast majority of respondents are police officers and in their ranks has more male. Female have a significant percentage of about $32 \%$, where the majority are employees of the education sector. Concerning education, the majority are with high school (55\%). About 29\% are employees with 6-11 years of work experience and 30\% have 0-5 years experience working in prison. Meanwhile, the majority of respondents age is the age of the status $37-47$. Regarding civil status $69 \%$ of them are married .A considerable part of them responded that they conducted training for CP. Around $60 \%$ responded that the distance from work is small.

The frequency with which respondents experience feelings related with each subscales measured with a seven-point scale: 0 (never); 1 (several times a year or less); 2 (a few times a month or less); 3 (a few times a month); 4 (once a week); 5 (several times a week) and 6 (every day).Depersonalization is conceived as a continuous variable, ranging from the lowest level, moderate and higher.

- A high level of Burnout is reflected in the high scores obtained in the subscale of Emotional exhaustion and depersonalization and low points in the Personal fulfillment subscale.

- A medium level of Burnout is reflected in the average scores obtained in the three subscales.

- A low level of Burnout is reflected in the low scores obtained in the Emotional exhaustion subscale and depersonalization and high scores in the Personal accomplishment subscale.

Table 2. The number of responses for each category

\begin{tabular}{|l|l|l|l|}
\hline Level & EE & DP & PA \\
\hline Low & 134 & 156 & 154 \\
\hline Average & 28 & 118 & 275 \\
\hline High & 27 & 38 & 185 \\
\hline
\end{tabular}

In this study is explored one of three subscales of burnout, depersonalization. The focus of this article is measuring of depersonalization and identification of factors influencing it. The foundations of burnout are to stress, as soon to know the symptoms of stress, and to address them, there are greater opportunities to prevent burnout. If the employees look irritated, nervous, unfocused, this is a beginning of depersonalization. They will be involved in behaviors such as the use of alcohol and the drugs or doing spending all day to escape from negative feelings. Also they begin to lose trust in others, believing that people are selfish. Dehumanized employees are cold, rigid, and indifferent to what was happening to prisoners. They treat prisoners like objects, they don't worry about their feelings, behaviors , opinions, requests. 


\section{Depersonalization}

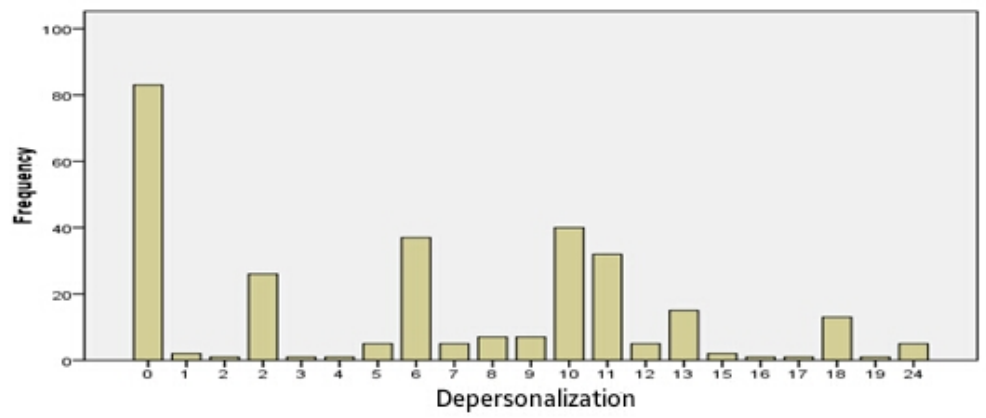

The rate of depersonalization (DP) consists of five elements that describe and measure the insensitivity (being hardhearted) and cold response, indifferent to recipients of services and care. For both subscales of emotional exhaustion and depersonalization, higher average scores corresponding high level of burnout. There is a moderate correlation between these two subscales, which is consistent with theoretical expectations where, aspects of burnout treated separately, but are related to each other. Depersonalization is the response to others with solidity, lack of caring for others and unfriendly reaction to others. Most of respondents in general had a small number of points. It was a small part of the show of depersonalization but in average levels.

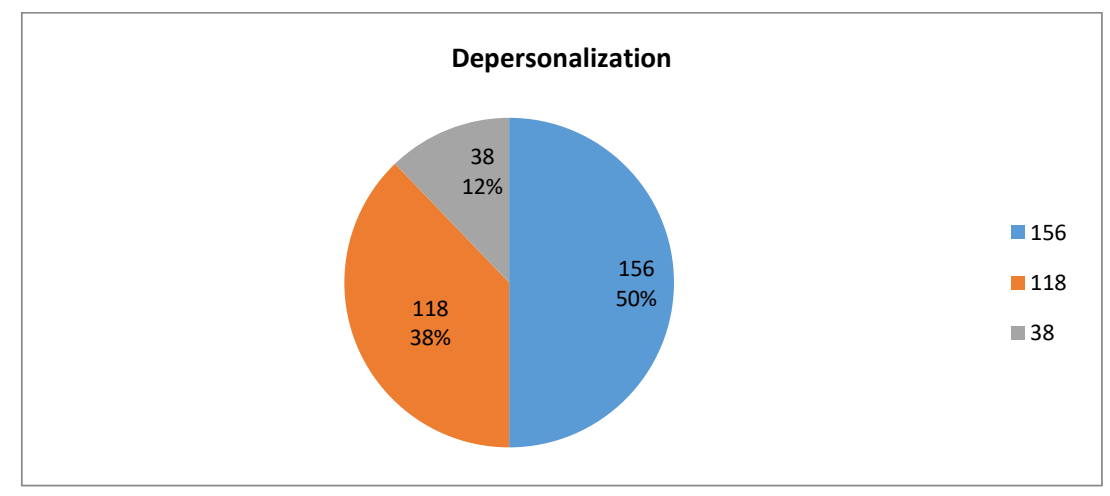

\section{The impact of factors in depersonalization}

\section{Age}

People who are aged less than 25 years have low levels of depersonalization. Higher level of depersonalization is seen on the workers aged $48-58$ years, but even in this case remain at the average level.

\section{Gender}

Men have higher depersonalization than women because they stay for a long time with the prisoners. There are fewer women than men respondents, because questionnaires were sent to institutions where there are more male than female employees. Secondly, the role that women have in prison is social workers, psychologists etc. These job positions have more moderate rate of depersonalization.

\section{Civil status}

Unmarried are dehumanized more than married, perhaps because they cannot share their concerns with relatives 


\section{Experience}

New employees are more likely to experience depersonalization compare with older employees, because they haven't adapted more with the job.

\section{Distance from work}

Higher depersonalization levels have people who have over 90 minutes distance from the workplace.

\section{Target group of working}

Employees who work with target of men, have normally higher rates of depersonalization. These rates are average. It happens because dangerousness.

\section{Shift work}

Those who have work with alternate shifts and especially with the third shift are more dehumanized.

\section{Relationships with superiors and colleagues}

The less level of communication and cooperation in organization the higher is the level of emotional exhaustion, consequently the level of depersonalization is higher.

\section{Conclusion}

As conclusion the prevalence of depersonalization is evident in prison staff, but in low levels. In general, women and men experience burnout, although there are some genders differences in the ways of experiencing.Women are more likely to experience emotional exhaustion and more intensively, while men are more inclined to go towards depersonalization, which usually leads to aggressive behavior towards customers. New employees are more likely to experience depersonalization compare with older employees, who have more years on the job, the more they deal with something, the more likely to adapt with it. Unmarried are dehumanized more than married, perhaps because they cannot share their concerns with relatives. Relationships between members family and friends, impact on depersonalization. As part of the support social system family and friends have a relaxing effect on stress caused by work. Studies have shown that when these relationships are positive, reduced burnout, but if these relations are in conflict, they increase the obligations and requirements, affecting performance at work.

\section{Recommendations}

Strategies to prevent burnout are individual, organizational and social. Work overload, high levels of emotional demands, lack of balance between work demands, control, supervision and support, bring depersonalization. If don't apply different strategies as personal as well as organizational or institutional, to help these employees maintain a balance between work and personal life, they may be in a difficult situation .Effectiveness and quality of their work may be damaged. And there is a possibility that their private lives be affected, as the consequences that come as a result of burnout can be long and dangerous

Correctional leaders must take the lead in order for burnout to be substantially reduced. To decrease the incidents of burnout among treatment staff, corrections administrators assigned to rehabilitative services are offered the following guidelines: (1) emphasize rehabilitation within a clear mission statement; (2) clarify roles and responsibilities; (3) empower staff; (4) offer constructive feedback; (5) manage by walking around; (6) provide treatment-based training and information; (7) hire competent treatment administrators; (8) balance the percentage of disruptive and violent offenders on caseloads; and (9) ensure that adequate office and group space are available. These guidelines will assist correctional managers in taking steps to improve the work lives and prevent burnout of treatment staff.

Acts that professionals must undertake in the workplace, to avoid depersonalization

- Have assistance and cooperation between employees 
- Consult with colleagues provide assistance to each other for difficult cases

- Have the opportunity to have a day off occasionally

- To have a balanced agenda and defined deadlines

- Have a care plan for them.

Individual strategies that employees must undertake to prevent depersonalization.

- Have enough time to realize the personal interests

- Development of various social activities

- Dedication of attention, time and care for themselves and their families

- Talk with a social worker to share concerns, their feelings to facilitate their emotional state .

\section{References}

[1] Ajdini.J. 2011. Probleme sociale, Tiranë, Shtëpia botuese: Albpaper

[2] Bob Mattheës,Liz Ross 2010 Metodat e Hulumtimit England

[3] Cheek, F., \& Miller, M. (1983). The experience of stress for correction officers: A double-blind theory of correctional stress. Journal of Criminal Justice, 11, 105-120.

[4] Cherniss, C. (1980). Staff burnout: Job stress in human services. Newbury Park, CA: Sage

[5] Correctional Psychologist Burnout, Job Satisfaction, and Life Satisfaction Aven Senter, Robert D. Morgan, Catherine Serna-McDonald, and Marshall Bewley Texas Tech University Psychological Services @ 2010 American Psychological Association 2010, Vol. 7, No. 3, 190-201

[6] Cropanzano, R., Rupp, D. E., \& Byrne, Z. S. (2003): The relationship of emotional exhaustion to work attitudes, job performance, and organizational citizenship behaviors. Journal of Applied Psychology, 88 (1), 160-169.

[7] Freudenberger.J.H m Staff burnout Journal of Social Issues Volume 30, Issue 1, pages 159-165, Winter 1974

[8] Griffin, M. L., Hogan, N. L., Lambert, E. G., Tucker-Gail, K. A., \& Baker, D. N. (2010): Job involvement, job stress, job satisfaction, and organizational commitment and the burnout of correctional staff. Criminal Justice and Behavior, 37 (2), 239-255.

[9] Jakson.S,Leiter.M,Maslach.CH 1986,Maslach burnout Inventory Manual.Mind Garden

[10] Karl, K., \& Peluchette, J. V. (2006): Does workplace fun buffer the impact of emotional exhaustion on job satisfaction? Journal of Behavioral and Applied Management, 7 (2), 128-141.

[11] Lee, C., \& Ashforth, B. E., (1996): A meta-analysis examination of the correlates of three dimensions of job burnout. Journal of Applied Psychology, 81, 123-133.

[12] Maslach, C. (1982): Burnout: The cost of caring. Englewood-Cliffs, NJ: Prentice Hall.

[13] Maslach, C., \& Jackson, S. E. (1981): The measurement of experienced burnout. Journal of Occupational Behavior, 2 (2), 99-113.

[14] Maslach, C., \& Leiter, M. P. (1997): The truth about burnout: How organizations cause personal stress and what to do about it. San Francisco, CA: Jossey-bass.

[15] Maslach, C., Jackson, S. E., \& Leiter, M. P. (1996): Maslach burnout inventory manual (3rd ed.). Palo Alto, CA: Consulting Psychologists Press.

[16] Maslach, C., Schaufeli, W. B., \& Leiter, M. (2001): Job burn out. Annual Review of Psychology, 52, 397-422. 
[17] Rama.R Sota .M Tahiri (Berisha).F Metodat kërkimore në shkencat sociale Tiranë : West print, 2013

[18] Roy, S., \& Avdija, A. S. (2012): The effect of prison security level on job satisfaction and job burnout among prison staff in the USA: An assessment. International Journal of Criminal Justice Sciences, 7 (2), 524-538.

[19] Sharma, A., Verma, S., Verma, C., \& Malhotra, D. (2010): Stress and burnout as predictors of job satisfaction among lawyers. European Journal of Social sciences, 14 (3), 348-359.

[20] Terry F.Pettijohn 1996 Psikologjia Tirane , Shtepia botuese :"Lilo" 